\title{
Article
}

\section{The family Pyrenidiaceae resurrected}

\section{Huanraluek $\mathbf{N}^{1}$, Ertz $\mathrm{D}^{3,5}$, Phukhamsakda $\mathbf{C}^{1}$, Hongsanan $\mathrm{S}^{2}$, Jayawardena $\mathbf{R S}^{1}$ and Hyde $\mathrm{KD}^{1,4^{*}}$}

\author{
${ }^{1}$ Center of Excellence in Fungal Research, and School of Science, Mae Fah Luang University, Chiang Rai 57100, \\ Thailand \\ ${ }^{2}$ Shenzhen Key Laboratory of Microbial Genetic Engineering, College of Life Sciences and Oceanography, Shenzhen \\ University, Shenzhen 518060, China \\ ${ }^{3}$ Department Research, Meise Botanic Garden, BE-1860 Meise, Belgium \\ ${ }^{4}$ Kunming Institute of Botany, Chinese Academy of Science, Kunming 650201, Yunnan, China \\ ${ }^{5}$ Fédération Wallonie-Bruxelles, Direction Générale de l'Enseignement non obligatorire et de la Recherche \\ scientifique, Rue A. Lavallée 1, B-1080 Bruxelles, Belgium
}

Huanraluek N, Ertz D, Phukhamsakda C, Hongsanan S, Jayawardena RS, Hyde KD 2019 - The family Pyrenidiaceae resurrected. Mycosphere 10(1), 634-654, Doi 10.5943/mycosphere/10/1/13

\begin{abstract}
Pyrenidium is a lichenicolous genus which was included in the family Dacampiaceae (Pleosporales) based on morphological characters. The classification of this genus within Dacampiaceae has been controversial due to the lack of sequence data. In this study, the genus Pyrenidium is sequenced for the first time using five freshly collected specimens belonging to the generic type and two other species. Although the morphology of Pyrenidium is quite similar to other genera of Dacampiaceae, phylogenetic analyses from nuLSU and nuSSU sequence data demonstrate that Pyrenidium is distantly related to Dacampiaceae and it forms a distinct lineage within the Dothideomycetes. Therefore, we resurrect the family Pyrenidiaceae to accommodate Pyrenidium. Morphological descriptions of the sequenced specimens of Pyrenidium are provided and include the description of a new species, $P$. borbonicum.
\end{abstract}

Key words - 1 new taxon - Dacampiaceae - Dothideomycetes - Lichenicolous fungi Phylogenetic analyses

\section{Introduction}

Dacampiaceae Körb. belongs to the order Pleosporales. Members of this family are represented by lichenicolous, lichenized and saprobic fungi which are characterized by blackish, perithecioid ascomata, pseudoparenchymatous exciple and brown ascospores (Hyde et al. 2013, Wijayawardene et al. 2018). Dacampiaceae was introduced by Körber (1855) and six genera are currently included: Aaosphaeria Aptroot., Dacampia A. Massal., Leptocucurthis Aptroot., Pseudonitschkia Coppins \& S.Y Kondr., Pyrenidium Nyl. and Weddellomyces Hawksw. (Hyde et al. 2013, Ertz et al. 2015, Wijayawardene et al. 2018, Doilom et al. 2018).

Pyrenidium was introduced by Nylander (1865), with P. actinellum Nyl. as the type species. Species of the genus are all lichenicolous and have perithecioid ascomata that often have bluegreen pigment located in upper peridial wall, and ascomata are immersed to erumpent in host thalli with the upper part exposed, or that are prominent but covered by tissue of the host thalli, sometimes causing gall-like malformations of the host (Hawksworth 1982, Eriksson \& 
Hawksworth 1993, Matzer 1996, Pirogov 2014, Lendemer 2017, Muscavitch et al. 2017, Diederich et al. 2018). The genus has been placed in Pyrenidiaceae Zahlbr., however, as Pyrenidium shares some similar morphological characters with Dacampia (Dacampiaceae Körb.), Hawksworth (1980) suggested a close relationship between Dacampiaceae and Pyrenidiaceae and the latter has been considered as a synonym of Dacampiaceae (Lumbsch \& Huhndorf 2010, Hyde et al. 2013, Wijayawardene et al. 2014, 2018, Jaklitsch et al. 2016). Crivelli (1983) suggested that Pyrenidium is similar to Dacampia by having similar ascomatal structures and wall tissues (Hawksworth 1977, Crivelli 1983,). However, these taxonomic assumptions have not been verified based on phylogenetic anlayses due to the lack of sequence data.

In this paper, we aim to provide morphological and molecular data for the genus Pyrenidium to clarify its phylogenetic placement. A phylogenetic tree including new sequence data from Pyrenidium generated by nuLSU and nuSSU is provided. Detailed morphological descriptions and illustrations of materials collected in Belgium, Madagascar and Reunion Island are included with notes.

\section{Materials \& Methods}

\section{Sample collection, morphological study and isolation}

Voucher specimens from Belgium, Madagascar and Reunion Island collected by the second author are deposited in BR (Meise Botanic Garden). They were morphologically studied and photomicrographs were made following the method of Thambugala et al. (2015). Dried herbarium materials were examined using a Motic SMZ 168 dissecting microscope to locate and isolate ascomata. Hand section of the fruiting structures were done and mounted in water, $5 \% \mathrm{KOH}(\mathrm{K})$, or $1 \%$ I2 Lugol's reagent without (I) or with $\mathrm{KOH}$ pre-treatment (K/I) for microscopic studies and photomicrography. The taxa were examined using a Nikon ECLIPSE 80i compound microscope and photographed with a Cannon 600D digital camera fitted to the microscope. Measurements were made by Tarosoft $(\mathrm{R})$ Image Frame Work program. Photoplates were prepared by using Adobe Photoshop CS6 Extended version 10.0 software (Adobe Systems, USA).

\section{DNA extraction, PCR amplification and sequencing}

Well-preserved and freshly collected specimens were used for sequencing. Hand sections of the hymenium were used for direct PCR as described in Ertz et al. (2015). The outer wall of perithecia was removed with a sterile razor blade to isolate the hymenium. The material was then added into a tube containing the PCR reaction mixture and amplified directly. Amplification reactions were prepared for $50 \mu \mathrm{l}$ final volume containing $5 \mu \mathrm{l} 10 \times$ DreamTaq Buffer (Thermo Scientific; www.thermoscientific.com/onebio), $1.25 \mu \mathrm{l}$ of each of the $20 \mu \mathrm{M}$ primers, $5 \mu \mathrm{l}$ of 2.5 mg ml-1 bovin serum albumin (Thermo Scientific \#B14), $4 \mu \mathrm{l}$ of $2.5 \mathrm{mM}$ each dNTPs (Thermo Scientfic), 1.25 U Dreamtaq DNA polymerase (Thermo Scientific), and tiny fragments of fungal material. DNA amplification was performed by polymerase chain reaction (PCR) using the primer pairs LIC15R (Miadlikowska et al. 2002) and LR6 (Vilgalys \& Hester 1990) to amplify the partial ribosomal RNA for the nuclear large subunit (28S, nuLSU), nssu131 (Kauff \& Lutzoni 2002) and NS24 (Gargas \& Taylor 1992) to amplify the partial ribosomal RNA for the nuclear small subunit (18S, nuSSU). The yield of the amplified products was verified by running the products on $1 \%$ agarose gel stained with ethidium bromide. Both strands were sequenced by Macrogen ${ }^{\circledR}$ using the same primers as for the PCR amplifications. Additional primers were used for sequencing LR3 for nuLSU (Vilgalys \& Hester 1990), and nssu1088 and nssu1088R for nuSSU (Kauff \& Lutzoni 2002). Sequenced fragments were assembled with Sequencher v.5.3 (Gene Codes Corporation, Ann Arbor, Michigan). Sequence data were subjected to MEGABLAST searches to verify their closest relatives and to detect potential contaminations. 


\section{Phylogenetic analyses}

Phylogenetic analyses were performed for combined nuLSU and nuSSU sequence data. The dataset of this study included 121 strains from GenBank (Table 1). Datasets were aligned by using MAFFT version 7.310 (Katoh \& Standley 2016: http://mafft.cbrc. jp/alignment/server/) and manually aligned wherever necessary in MEGA version 6.0 (Tamura et al. 2013). The sequence datasets were combined using the CIPRES Science Gateway version 3.3. (Miller et al. 2011). RAxML rapid bootstrapping and subsequent ML search used distinct model/data partitions with joint branch length optimization, 1000 rapid bootstrap inferences and thereafter a thorough ML search, all free model parameters were estimated by RAxML, ML estimate of 50 per site rate categories. Likelihood of final tree was evaluated and optimized under GAMMA+P-Invar. Model parameters were estimated up to an accuracy of $0.1000000000 \mathrm{Log}$ Likelihood units. Maximumparsimony (MP) analyses were carried out using PAUP version 4.0b10 (Swofford 2002). Parsimony bootstrap analyses were performed using the full heuristic search option, random stepwise addition and 1000 replicates with maxtrees set at 5000 (will not be increased).

The model for Bayesian inference analysis was determined by using MrModeltest 2.3 (Nylander 2004) and the GTR $+\mathrm{I}+\mathrm{G}$ nucleotide substitution model was used for each partition. Posterior probabilities (PP) were performed (Rannala \& Yang 1996, Zhaxybayeva \& Gogarten 2002) in MrBayes V. 3.2 (Ronquist et al. 2011). Phylogenetic trees were illustrated in Fig Tree Drawing Tool version 1.4.0 (Rambaut 2012). Bootstrap support values (> ML 60\%/MP 60\%/BYPP 0.60) are indicated on the branches of the tree (Fig. 1).

\section{Results}

\section{Phylogenetic analyses}

The combined nuLSU and nuSSU sequence data comprised 121 strains, including strains of Pyrenidium ( $P$. cf. actinellum Ertz 18063, P. actinellum Nyl. sensu stricto. Ertz 16557, P. borbonicum Ertz 18031, P. borbonicum Ertz 18066 and $P$. aff. aggregatum Ertz 20089). Acolium tigillare (AFTOL-ID4839) (Caliciaceae) in Lecanoromycetes was selected as an outgroup.

Maximum parsimony, maximum likelihood and Bayesian inference resulted in similar topologies. Therefore, only the Maximum parsimony tree is presented, with the support values of the maximum likelihood and the Bayesian inference analyses (Fig. 1). Parsimony analysis comprised a dataset of 1619 total characters, of which 730 characters were constant, 725 parsimony-informative and 164 parsimony-uninformative. The first tree generated among 1000 equally parsimonious trees is selected (Fig. $1 ; \mathrm{TL}=3724, \mathrm{CI}=0.366, \mathrm{RI}=0.732, \mathrm{RC}=0.268, \mathrm{HI}=$ $0.634)$.

The phylogenetic tree obtained from Maximum parsimony tree showed that the taxa of Pyrenidium form the clade with high bootstrap support outside the family Dacampiaceae (Fig. 1). The clade of Pyrenidium forms a lineage related to Natipusillaceae (Natipusillales), Microthyriaceae (Microthyriales) and Zeloasperisporiaceae (Zeloasperisporiales). However, the external node does not receive support. The best scoring tree obtained from maximum likelihood analysis received a final value of -20235.541082 .

Table 1 Specimens and DNA sequences used in this study, with their respective voucher information. Sequences generated in this study are in blue and ex-type strains are in bold and shown by a $\mathrm{T}$ after the strain number.

\begin{tabular}{llcc}
\hline \multicolumn{1}{c}{ Species } & \multicolumn{1}{c}{ Culture collection } & \multicolumn{2}{c}{ GenBank accession numbers } \\
\cline { 3 - 4 } & & nuLSU & nuSSU \\
\hline Acolium tigillare & AFTOL-ID 4839 & JQ301593 & JQ301646 \\
Acrocordiopsis patilii & BCC 28166 $^{\mathbf{T}}$ & GU479772 & GU479736 \\
Acrocordiopsis patilii & BCC 28167 & GU479773 & GU479737 \\
Aigialus grandis & BCC 20000 $^{\mathbf{T}}$ & GU479775 & GU479739 \\
\hline
\end{tabular}


Table 1 Continued.

\begin{tabular}{|c|c|c|c|}
\hline \multirow[t]{2}{*}{ Species } & \multirow[t]{2}{*}{ Culture collection } & \multicolumn{2}{|c|}{ GenBank accession numbers } \\
\hline & & nuLSU & nuSSU \\
\hline Aigialus mangrovis & ВCС 33563 & GU479776 & GU479741 \\
\hline Aigialus mangrovis & BCC 33564 & GU479777 & GU479742 \\
\hline Aigialus parvus & BCC 18403 & GU479778 & GU479744 \\
\hline Alternaria alternata & AFTOL-ID 1610 & DQ678082 & DQ678031 \\
\hline Alternariaster helianthi & CBS 199.86 ${ }^{\mathrm{T}}$ & КС609343 & - \\
\hline Anteaglonium globosum & GKML101N & GQ221875 & - \\
\hline Antennariella placitae & CBS 124785 & GQ303299 & - \\
\hline Aquastroma magniostiolata & KT $2485^{\mathrm{T}}$ & AB807510 & AB797220 \\
\hline Aquaticheirospora sp. & RK-2006a & AY736378 & AY736377 \\
\hline Aquilomyces patris & CBS $135661^{T}$ & KP184041 & - \\
\hline Arthopyrenia salicis & CBS 368.94 & AY538339 & AY538333 \\
\hline Ascochyta phacae & CBS 184.55 & KT389692 & - \\
\hline Ascocylindrica marina & MD6011 $^{\mathrm{T}}$ & KT252905 & KT252907 \\
\hline Asteromassaria pulchra & CBS 124082 & GU301800 & GU296137 \\
\hline Bambusicola massarinia & MFLUCC 11-0389 ${ }^{\mathrm{T}}$ & JX442037 & JX442041 \\
\hline Capnodium salicinum & AFTOL-ID 937 ${ }^{\mathrm{T}}$ & DQ678050 & - \\
\hline Clypeoloculus akitaensis & KT $788^{T}$ & AB807543 & AB797253 \\
\hline Cryptoclypeus oxysporus & KT 2772 & LC194345 & LC194303 \\
\hline Dacampia engeliana & Hafellner 72868 & KT383791 & - \\
\hline Dacampia hookeri & Hafellner73897 (GZU) ${ }^{\mathrm{T}}$ & KT383792 & - \\
\hline Dacampia hookeri & Hafellner74269 (GZU) & KT383793 & - \\
\hline Dacampia hookeri & Hafellner75980 (GZU) & KT383794 & - \\
\hline Dacampia hookeri & Hafellner81840 (GZU) & KT383795 & - \\
\hline Delitschia anisomera & GKM 1205 & GU385171 & DQ678026 \\
\hline Delitschia chaetomioides & GKM 1283 & GU385172 & JX254656 \\
\hline Delitschia winteri & AFTOL-ID 1599 & DQ678077 & DQ018079 \\
\hline Deniquelata barringtoniae & MFLUCC 11-0422T & JX254655 & JX254656 \\
\hline Dictyosporium elegans & NBRC 32502 ${ }^{\mathrm{T}}$ & DQ018100 & DQ0181079 \\
\hline Didymella exigua & CBS 183.55 & EU754155 & - \\
\hline Didymocyrtis cf. epiphyscia & Ertz $17411(\mathrm{BR})$ & KT383799 & - \\
\hline Didymocyrtis consimilis & $\begin{array}{l}\text { Voucher Gardiennet } \\
1_{12041^{T}}\end{array}$ & KT383796 & - \\
\hline Didymosphaeria rubi-ulmifolii & MFLUCC 14-0024 & KJ436585 & KJ436587 \\
\hline Digitodesmium bambusicola & CBS 110279 & DQ018103 & - \\
\hline Dothidotthia aspera & CPC 12933 & EU673276 & EU673228 \\
\hline Dothidotthia symphoricarpi & CPC $1^{12929}{ }^{\mathrm{T}}$ & EU673273 & - \\
\hline Elsinoe verbenae & CPC 18561 & KX887061 & JN940562 \\
\hline Extremus antarcticus & CCFEE 5312 & KF310020 & - \\
\hline Falciformispora lignatilis & BCC 21118 & GU371827 & GU371835 \\
\hline Fuscostagonospora sasae & KT $1467^{T}$ & AB807548 & AB797258 \\
\hline Gregarithecium curvisporum & KT 922 & AB807547 & AB797257 \\
\hline Halomassarina thalassiae & JK 5262D & GU301816 & - \\
\hline Halotthia posidoniae & BBH $22481^{T}$ & GU479786 & GU479752 \\
\hline Hysterium angustum & CBS 236.34 & FJ161180 & GU397359 \\
\hline Kalmusia brevispora & KT 1466 & AB524600 & AB524459 \\
\hline Keissleriella cladophila & CBS 104.55 & GU205221 & GU296155 \\
\hline Kirschsteiniothelia elaterascus & HKUCC7769 & AY787934 & - \\
\hline Lentithecium fluviatile & CBS $122367^{T}$ & GU301825 & GU296158 \\
\hline Lepidosphaeria nicotiae & CBS 559.71 ${ }^{\mathrm{T}}$ & DQ384106 & DQ384068 \\
\hline Leptosphaeria doliolum & CBS 505.75 & GQ387576 & GQ387515 \\
\hline
\end{tabular}


Table 1 Continued.

\begin{tabular}{|c|c|c|c|}
\hline \multirow[t]{2}{*}{ Species } & \multirow[t]{2}{*}{ Culture collection } & \multicolumn{2}{|c|}{ GenBank accession numbers } \\
\hline & & nuLSU & nuSSU \\
\hline Leptosphaeria maculans & CBS 260.94 & JX681096 & - \\
\hline Leptoxyphium cacuminum & MFLUCC10-0049 & JN832602 & JN832587 \\
\hline Lichenoconium aeruginosum & JL359-09 & HQ174269 & HQ174268 \\
\hline Lichenoconium erodens & JL363-09 & HQ174267 & HQ174266 \\
\hline Lichenoconium lecanorae & JL382 & HQ174263 & HQ174262 \\
\hline Lichenoconium usneae & JL352-09 & HQ174265 & HQ174264 \\
\hline Lindgomyces ingoldianus & ATCC $200398^{T}$ & AB521736 & AB521720 \\
\hline Longipedicellata aptrootii & MFLUCC 10-0297 ${ }^{\mathrm{T}}$ & KU238894 & KU238895 \\
\hline Lophiostoma macrostomum & $\mathrm{KT}^{\mathrm{T} 5 \mathrm{~B}^{\mathrm{T}}}$ & AB619010 & AB618691 \\
\hline Lophiotrema nucula & CBS 627.86 ${ }^{\mathrm{T}}$ & GU301837 & GU296167 \\
\hline Lophium mytilinum & AFTOL-ID $1609^{T}$ & DQ678081 & DQ678030 \\
\hline Macrodiplodiopsis desmazieri & CPC 24971 ${ }^{\mathrm{T}}$ & KR873272 & - \\
\hline $\begin{array}{l}\text { Magnicamarosporium } \\
\text { iriomotense }\end{array}$ & KT $2822^{T}$ & AB807509 & AB797219 \\
\hline Massarina ramunculicola & BCC 18404 & GQ925853 & GQ925838 \\
\hline Massariosphaeria typhicola & CBS 609.86 & EF165033 & EF165037 \\
\hline Melanomma pulvis-pyrius & CBS 371.75 & GU301845 & FJ201989 \\
\hline Microthyrium microscopicum & CBS 115976 ${ }^{T}$ & GU301846 & GU296175 \\
\hline Microthyrium sp. & MFLUCC 15-0213 & KT306552 & KT306550 \\
\hline Montagnula aloes & CBS 132531 & JX069847 & - \\
\hline Multilocularia bambusae & MFLUCC 11-0180 ${ }^{\mathrm{T}}$ & KU693438 & KU693442 \\
\hline Multiseptospora thailandica & MFLUCC 11-0183 ${ }^{\mathrm{T}}$ & KP744490 & KP753955 \\
\hline Murilentithecium clematidis & IT1078 $^{\mathrm{T}}$ & KM408758 & KM408760 \\
\hline Myriangium duriaei & CBS 260.36 & NG027579 & - \\
\hline Mytilinidion rhenanum & CBS 135.45 & FJ161175 & - \\
\hline Natipusilla bellaspora & OTU-0-0212.44 & MF331811 & \\
\hline Natipusilla bellaspora & PE91-1a & JX474863 & JX474868 \\
\hline Natipusilla bellaspora & PE91-1b & JX474864 & JX474869 \\
\hline Natipusilla decorospora & LA236.1A $A^{T}$ & HM196369 & - \\
\hline Natipusilla limonensis & $\mathrm{L}-\mathrm{AF} 286-1 \mathrm{~A}$ & HM196370 & HM196377 \\
\hline Natipusilla limonensis & PE3-2a & JX474861 & JX474867 \\
\hline Natipusilla limonensis & PE3-2b & JX474862 & JX474870 \\
\hline Natipusilla naponensis & LAF217-1A & HM196371 & HM196378 \\
\hline Natipusilla naponensis & LAF $217-1 \mathrm{~B}$ & HM196372 & HM196379 \\
\hline Neoastrosphaeriella krabiensis & MFLUCC11-0025 ${ }^{\mathrm{T}}$ & JN846729 & JN846739 \\
\hline Neoastrosphaeriella sp. & MFLUCC 18-0209 & MK138829 & MK138789 \\
\hline $\begin{array}{l}\text { Neoastrosphaeriella } \\
\text { sribooniensis }\end{array}$ & MFLUCC 13-0834 & MF588997 & MF588987 \\
\hline Neobambusicola strelitziae & CBS 138869 $^{\mathrm{T}}$ & KP004495 & - \\
\hline Parabambusicola bambusina & KT $2637^{T}$ & AB807538 & - \\
\hline Periconia homothallica & KT 916 & AB807565 & AB797275 \\
\hline Phaeosphaeria oryzae & CBS 110110 & GQ387591 & GQ387530 \\
\hline Pleomassaria siparia & AFTOL-ID $1600^{T}$ & DQ678078 & DQ678027 \\
\hline $\begin{array}{l}\text { Pleospora herbarum var. } \\
\text { herbarum }\end{array}$ & CBS 191.86 ${ }^{\mathrm{T}}$ & JX681120 & - \\
\hline Polyschema terricola & CBS 301.65 & EF204504 & EF204519 \\
\hline Preussia funiculate & CBS 659.74 & GU301864 & GU296187 \\
\hline Pseudoasteromassaria fagi & $\mathrm{KT}^{\mathrm{T}} \mathbf{3 3 2}^{\mathrm{T}}$ & LC061590 & LC061585 \\
\hline $\begin{array}{l}\text { Pseudocoleophoma } \\
\text { calamagrostidis }\end{array}$ & $\mathrm{KT3284}^{\mathrm{T}}$ & LC014609 & LC014604 \\
\hline
\end{tabular}


Table 1 Continued.

\begin{tabular}{|c|c|c|c|}
\hline \multirow[t]{2}{*}{ Species } & \multirow[t]{2}{*}{ Culture collection } & \multicolumn{2}{|c|}{ GenBank accession numbers } \\
\hline & & nuLSU & nuSSU \\
\hline Pseudodictyosporium wauense & NBRC 30078 & DQ018105 & DQ018083 \\
\hline Pseudomonodictys tectonae & MFLUCC 12-0552 & KT285573 & KT285574 \\
\hline Pseudoxylomyces elegans & KT $2887^{T}$ & AB807598 & AB797308 \\
\hline $\begin{array}{l}\text { Pyrenidium actinellum Nyl. } \\
\text { sensu stricto. }\end{array}$ & Ertz 16557 & MK713524 & - \\
\hline Pyrenidium aff. aggregatum & Ertz 20089 & MK713526 & - \\
\hline Pyrenidium borbonicum & Ertz 18031 & MK713527 & MK713523 \\
\hline Pyrenidium borbonicum & Ertz 18066 & MK713528 & MK713522 \\
\hline Pyrenidium cf. actinellum & Ertz 18063 & MK713525 & MK713521 \\
\hline Repetophragma ontariense & HKUCC 10830 & DQ408575 & - \\
\hline Rhytidhysteron opuntiae & GKM1190 & GQ221892 & - \\
\hline Rhytidhysteron rufulum & AFTOL-ID 2109 & FJ469672 & - \\
\hline Salsuginea ramicola & KT 2597.2 & GU479801 & GU479768 \\
\hline Splanchnonema platani & CBS 221.37 & JX681100 & - \\
\hline Stagonospora pseudocaricis & CBS 135132 & KF251762 & - \\
\hline Sulcatispora acerina & $\mathrm{KT}^{\mathrm{T}} 2982^{\mathrm{T}}$ & LC014610 & LC014605 \\
\hline Tetraplosphaeria sasicola & KT $563^{T}$ & AB524631 & AB524490 \\
\hline Trematosphaeria pertusa & CBS 122368 $^{\mathrm{T}}$ & FJ201990 & FJ201991 \\
\hline Ulospora bilgramii & AFTOL-ID $1598^{T}$ & DQ678076 & DQ678025 \\
\hline Wicklowia aquatic & F76-2 $2^{T}$ & GU045445 & - \\
\hline Wicklowia aquatica & AF289-1 & GU045446 & - \\
\hline Zeloasperisporium wrightiae & MFLUCC 15-0225 & KT387737 & KT387738 \\
\hline Zopfia rhizophila & CBS 207.26 ${ }^{\mathrm{T}}$ & DQ384104 & DQ384086 \\
\hline
\end{tabular}

\section{Taxonomy}

Pyrenidiaceae Zahlbr., in Engler, Syllabus der Pflanzenfamilien, Edn 2 (Berlin): 46 (1898)

Type genus - Pyrenidium Nyl.

The Pyrenidiaceae was a synonym of Dacampiaceae, however based on our phylogenetic results herein we resurrect the family Pyrenidiaceae. It includes only the genus Pyrenidium (Fig. 1).

Pyrenidium Nyl., Flora, Regensburg 48: 210 (1865)

Type species - Pyrenidium actinellum Nyl.

Ascomata perithecioid, densely grouped or dispersed over large areas of the thallus sessile or immersed in the host-thallus, usually black, in longitudinal section subglobose to broadly ovoid or pyriform, often with light greenish-blue tint in ostiolar channel. Peridium with isodiametric to elongated cells, brown to dark brown. Hymenium hyaline, I-, KI-. Hamathecial filaments numerous, persistent, pseudoparaphyses, branched and anastomosing and periphyses nonbranching, apical cells not enlarged. Asci 4-8-spored, bitunicate, shortly pedicellate, I-, KI-, ocular chamber not distinct. Ascospores dark brown, often paler brown in the spore tips, smooth. Asexual morph: Unknown.

Notes - Lichenicolous, associated with various unrelated hosts occurring on various substrates such as bark, rock, soil, bryophytes or living leaves. The genus Pyrenidium has a cosmopolitan distribution (Hawksworth 1980, 1983, Matzer 1996, Navarro-Rosinés \& Roux 2007, Knudsen \& Kocourková 2010, Aptroot 2014, Doilom et al. 2018). 


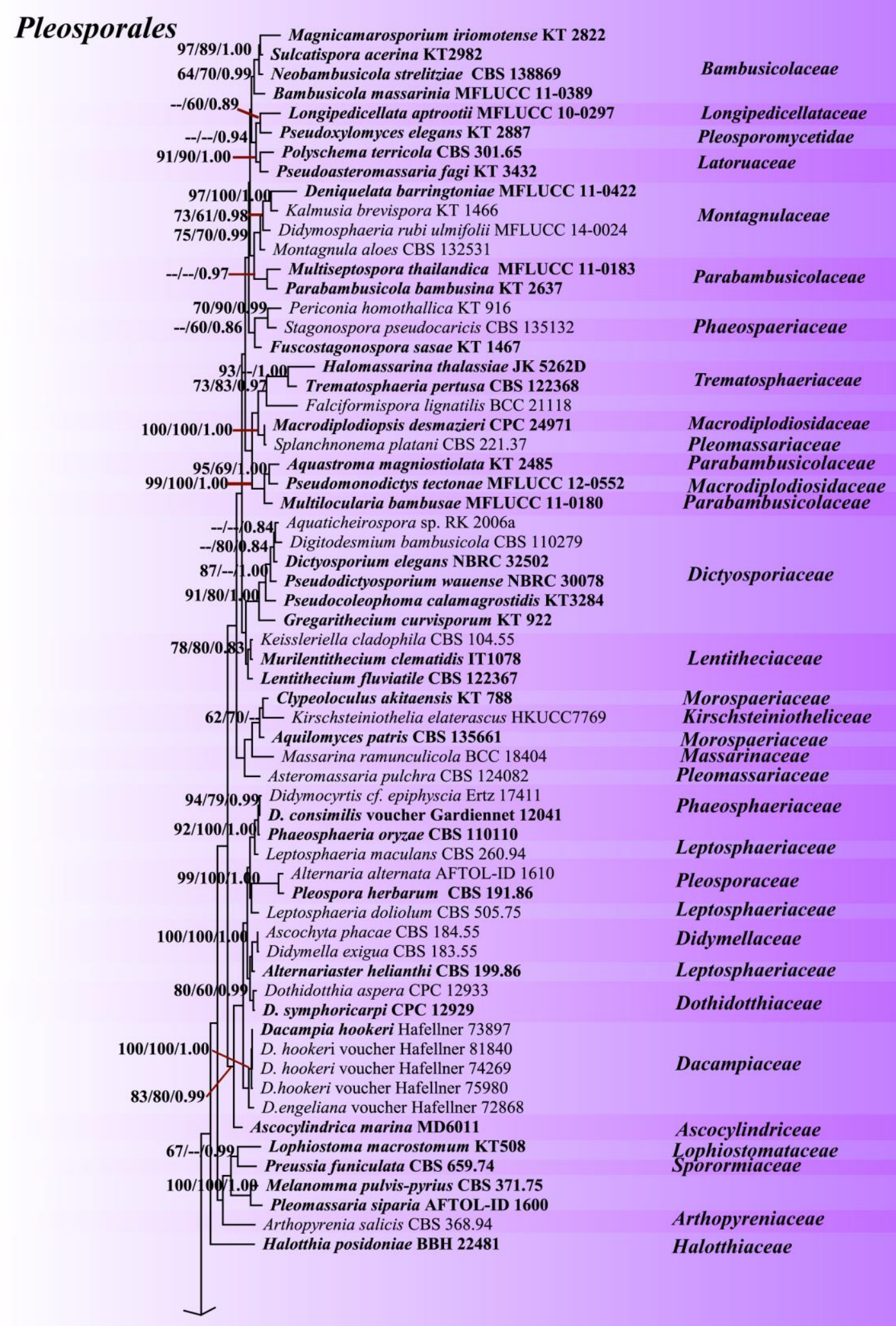

Figure 1- Phylogram generated from Maximum Parsimony tree of combined nuLSU and nuSSU sequence data of representative species in Dothideomycetes. Bootstrap support values (>ML 60\%/MP 60\%/BYPP 0.60) are given above the branches. Culture accession numbers are mentioned along with the species name. The tree is rooted by Acolium tigillare (AFTOL-ID4839) in Lecanoromycetes. Types are in black bold, and the strains of Pyrenidiaceae are highlighted in blue bold. 


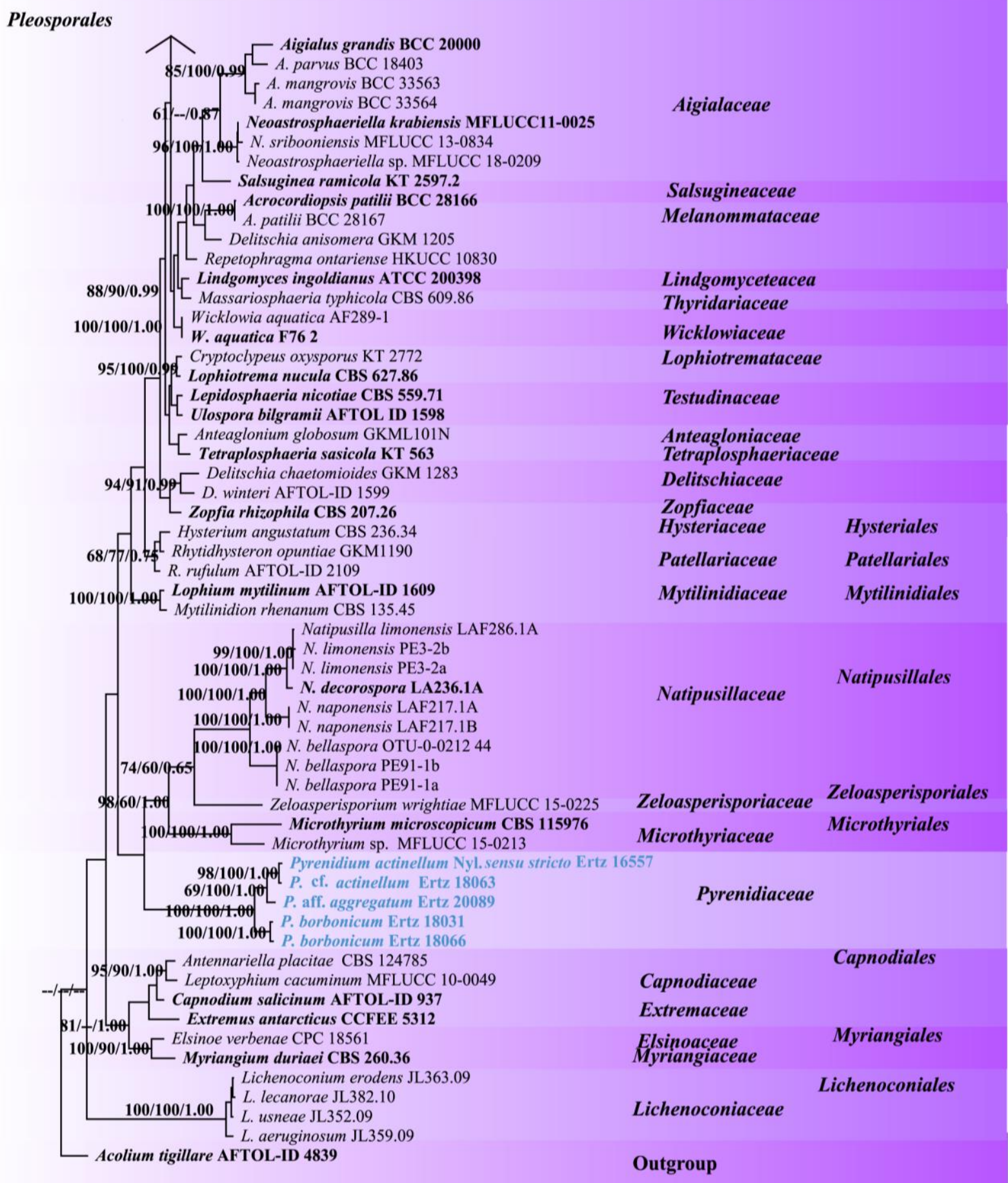

Figure 1 - Continued.

Pyrenidium actinellum Nyl. sensu stricto

Index Fungorum number: IF403001; Facesoffungi number: FoF04634

Fig. 2

Ascomata 175-380 $\mu \mathrm{m}$ high (130-188 $\mu \mathrm{m}$ high, Doilom et al. 2018), 162-350 $\mu \mathrm{m}$ diam. (150$190 \mu \mathrm{m}$ diam, Doilom et al. 2018), sessile or rarely semi-immersed on host thalli, scattered, solitary or 2-4 contiguous, black, subglobose to pyriform, ostiole central, with pore-like opening; without distinct gall formation or with barely visible malformations of the host thallus. Peridium 30-50 $\mu \mathrm{m}$ wide (25-50 $\mu \mathrm{m}$ wide, Doilom et al. 2018), thick-walled, composed of several layers of dark brown 
to reddish brown pseudoparenchymatous cells, arranged in textura angularis to textura prismatica, inner layers comprising hyaline cells. Hamathecium composed of dense, filiform, anastomosed, cellular pseudoparaphyses $1.5-2.5 \mu \mathrm{m}$ wide (1.5-2.5 $\mu \mathrm{m}$ wide, Doilom et al. 2018), constricted at the septa, embedded in a gelatinous matrix. Asci 75-80 × 12-16 $\mu \mathrm{m}(\mathrm{n}=3)(40-88 \times 11-18 \mu \mathrm{m}$, Doilom et al. 2018), 4-spored, subcylindrical, apically rounded with indistinct ocular chamber. Ascospores $18-26 \times 7.5-11 \mu \mathrm{m}(\bar{x}=23.1 \times 9.5 \mu \mathrm{m}, \mathrm{n}=30)(19-27 \times 7-9 \mu \mathrm{m}$, Doilom et al. 2018), overlapping 1-2-seriate, pale brown in immature state, reddish brown to dark brown in mature state, paler in the spore tips, oblong to ellipsoidal, or fusiform, rounded or obtuse at the apex, usually 3-septate, constricted at the septa with the two inner cells much larger than the end cells.

Asexual morph: undetermined.

Material examined - BELGIUM, Aywaille, right bank of the Amblève river, Heid des Gattes, $200 \mathrm{~m}$ elev. sandstone rocky slope with Anema, on the lichen Scytinium plicatile, 2011, Ertz 16557 (BR).

Notes - Pyrenidium actinellum was introduced by Nylander (1865), and was described from Scytinium teretiusculum (Wallr.) Otálora et al. sensu lato (= Leptogium teretiusculum (Wallr.) Arnold). The type specimen was described and illustrated in more details by Doilom et al. (2018). Pyrenidium actinellum is characterized by perithecioid ascomata with a bluish green hue (not or barely visible in our specimen 16557, and in the type according to the figure in Doilom et al. (2018), 4-spored, subcylindrical asci and brown to dark brown, paler at the ends, ellipsoidal, 3septate ascospores (Hawksworth 1983, Navarro-Rosinés \& Roux 2007, Knudsen \& Kocourková 2010).

The type specimen of $P$. actinellum and our sequenced specimen 16557 grow on the cyanolichen genus Scytinium ( $S$. teretiusculum and $S$. plicatile respectively). The latter specimen differs from the type specimen by larger perithecia, which are semi-immersed on the host thalli. Pyrenidium actinellum has been reported from a wide range of lichen hosts, but our molecular analyses suggest that more species are involved in this complex, of which one is described here as new. Sequencing of specimens of $P$. actinellum sensu lato from other hosts lichen genera will likely reveal a higher cryptic diversity in the genus.

Pyrenidium cf. actinellum Nyl.

Index Fungorum number: IF403001; Facesoffungi number: FoF04634

Fig. 3

Ascomata 168-205 $\mu \mathrm{m}$ high $(130-188 \mu \mathrm{m}$ high, Doilom et al. 2018) $\times 117-179 \mu \mathrm{m}$ diam. (150-190 $\mu \mathrm{m}$ diam, Doilom et al. 2018), $(\bar{x}=187 \times 146 \mu \mathrm{m}, \mathrm{n}=5)$, numerous, evenly dispersed over large areas of the thallus, immersed in the host-thallus, only the upper, blackish part of the ascomata visible, ascomata in longitudinal section subglobose to broadly ovoid, with light greenishblue tint it ostiolar channel. Peridium 22-36 $\mu \mathrm{m}$ wide, composed of 5-9 layers of textura prismatica, with isodiametric to elongated cells, brown to dark brown. Hymenium not inspersed. Hamathecial filaments numerous, persistent, composed of pseudoparaphyses, 1-2 $\mu \mathrm{m}$ diam., richly branched and anastomosing, developing between the asci, and periphyses 1-2 $\mu \mathrm{m}$ wide (1.5-2.5 $\mu \mathrm{m}$ wide, Doilom et al. 2018), with light greenish-blue tint in ostiole region, apical cell not enlarged. Asci 51-115 × 12-18 $\mu \mathrm{m}(\bar{x}=84 \times 16 \mu \mathrm{m}, \mathrm{n}=20),(40-88 \times 11-18 \mu \mathrm{m}$, Doilom et al. 2018), 4-spored, narrowly ellipsoid, ocular chamber not distinct. Ascospores 20-25 $\times 6-11 \mu \mathrm{m}(\bar{x}=$ $23 \times 9 \mu \mathrm{m}, \mathrm{n}=20),(19-27 \times 7-9 \mu \mathrm{m}$, Doilom et al. 2018), biseriate, partially overlapping, dark brown, $\mathrm{K}+$ turning black, often paler brown in the spore tips, narrowly ellipsoid, 3-septate, sometimes slightly curved toward the ends, constricted at the septa, without a gelatinous sheath. Asexual morph: undetermined.

Material examined - FRANCE, Reunion; Cilaos, trail to the Col du Taibit, just before the pass, ca 2,010m, 21 $06^{\prime} 47^{\prime}$ 'S, $55^{\circ} 26^{\prime} 03^{\prime \prime}$, rocky slope under Erica gr arborea on the edge of a path, on Solorina simensis (Peltigeraceae) 2012, Ertz 18063 (BR).

Notes - see under Pyrenidium actinellum sensu stricto. Our specimen likely represents $P$. actinellum because of a similar morphology and our phylogenetic results (Fig. 1). However, as the 
host lichen genus is different, we refrain to include it into $P$. actinellum sensu stricto until the host range will be studied.
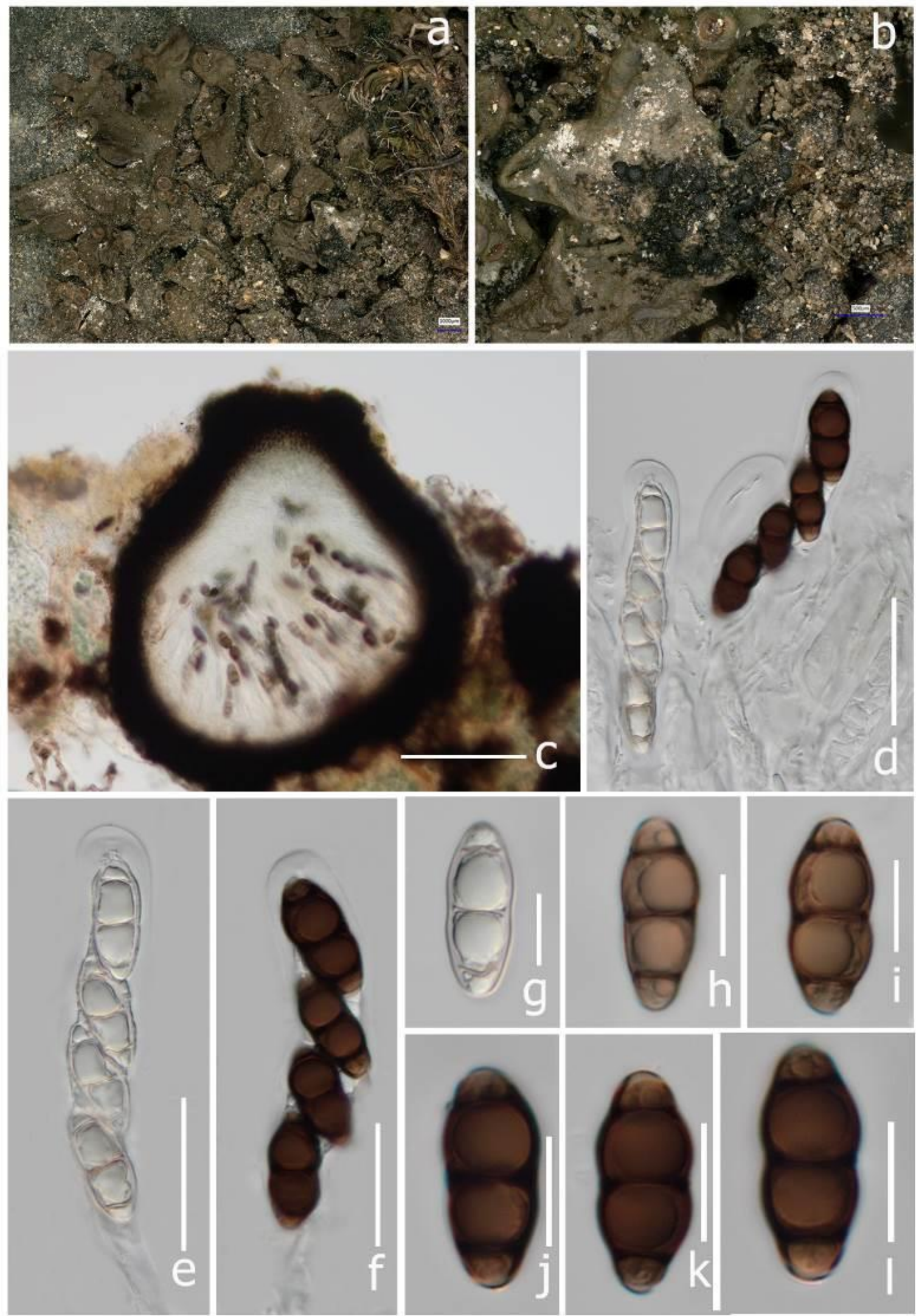

Figure 2 - Pyrenidium actinellum Nyl sensu stricto. (Ertz 16557) a, b Appearance of ascomata on host surface. c Vertical section of host with perithecioid ascomata visible. d Hymenium with asci. e, f Asci. g-1 Ascospores. Scale bars: $\mathrm{c}=50 \mu \mathrm{m}, \mathrm{d}=10 \mu \mathrm{m}, \mathrm{e}, \mathrm{f}=10 \mu \mathrm{m}, \mathrm{g}-1=5 \mu \mathrm{m}$. 


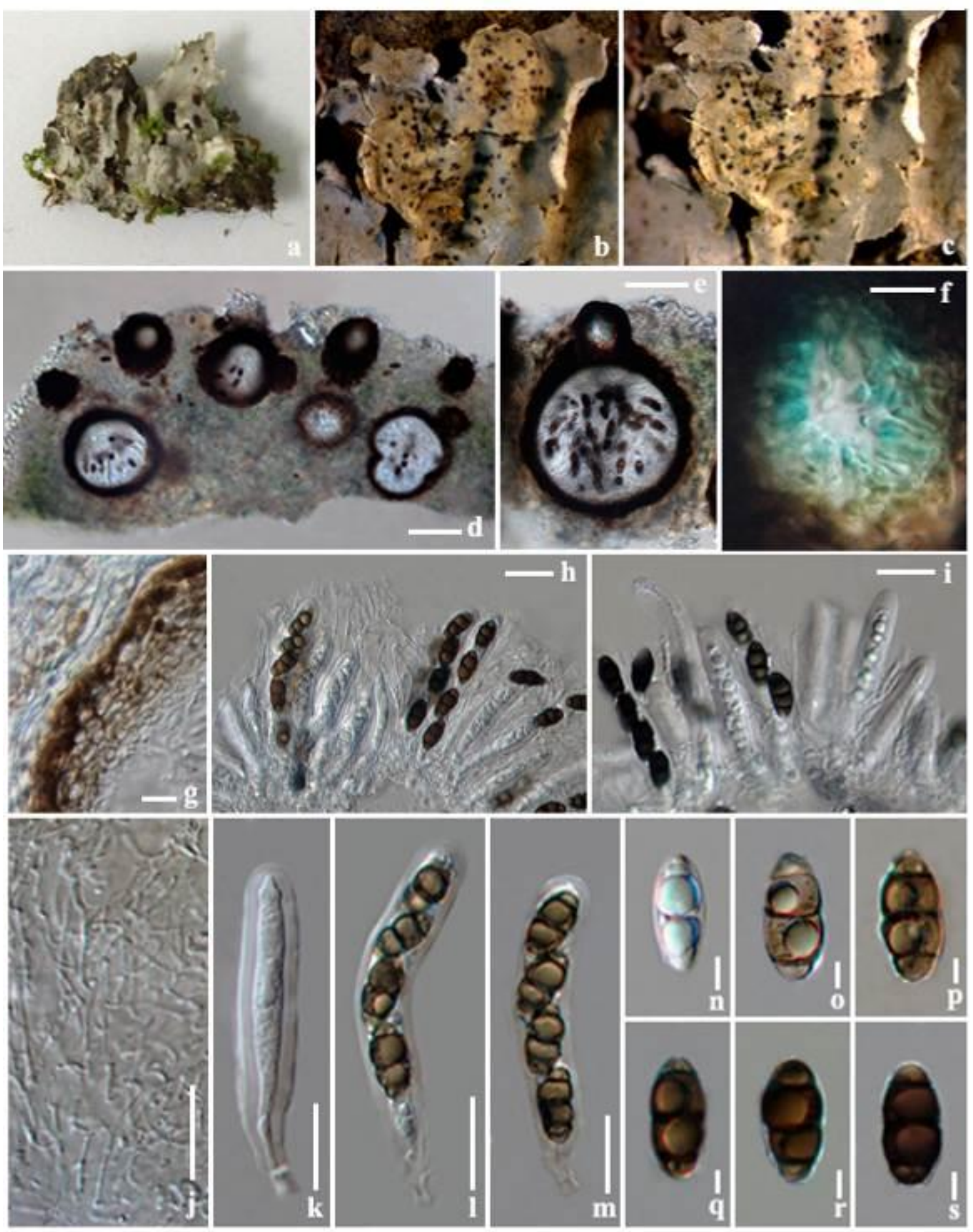

Figure 3 - Pyrenidium cf. actinellum (Ertz 18063) a-c Appearance of ascomata on host surface. $\mathrm{d}$ Vertical section of host with perithecioid ascomata visible. e Vertical section of perithecioid ascoma. f Ostiolar channel. g Peridium. h Hymenium with asci in water. i Hymenium with asci in $\mathrm{KOH}$. j Pseudoparaphyses. k-m Asci. $\mathrm{n}-\mathrm{s}$ Ascospores. Scale bars: $\mathrm{d}-\mathrm{e}=50 \mu \mathrm{m}, \mathrm{f}=50 \mu \mathrm{m}, \mathrm{g}=10$ $\mu \mathrm{m}, \mathrm{h}=20 \mu \mathrm{m}, \mathrm{i}=20 \mu \mathrm{m}, \mathrm{j}=20 \mu \mathrm{m}, \mathrm{k}-\mathrm{m}=20 \mu \mathrm{m}, \mathrm{n}-\mathrm{s}=5 \mu \mathrm{m}$. 
Ascomata $45-106 \times 33-79 \mu \mathrm{m}(\bar{x}=73 \times 53 \mu \mathrm{m}, \mathrm{n}=10)$, solitary or crowded, immersed in gall-like malformations of the host thallus, blackish part arises from host thallus, 2-15 ascomata in one gall, galls strongly convex, of the same colour of the thallus, $0.4-1.3 \mathrm{~mm}$, ascomata in longitudinal section subglobose to broadly ovoid, with light greenish-blue tint in ostiolar channel. Peridium 9-12 $\mu \mathrm{m}$ wide, composed of 3-9 layers of textura prismatica, with isodiametric to elongated cells, brown to dark brown. Hymenium not inspersed. Hamathecial filaments numerous, composed of pseudoparaphyses, 1-3 $\mu \mathrm{m}$ diam., richly branched and anastomosing, developping between asci, and periphyses $15-20 \times 3-4 \mu \mathrm{m}(\bar{x}=18 \times 3 \mu \mathrm{m}, \mathrm{n}=10)$, with light greenish-blue tint in ostiole region, apical cell not enlarged. Asci 48-87 $\times 11-18 \mu \mathrm{m}(\bar{x}=71 \times 14 \mu \mathrm{m}, \mathrm{n}=20)$, 8spored, narrowly ellipsoid, ocular chamber not distinct. Ascospores 18.8-22.2 $\times 7-8.5 \mu \mathrm{m}(\bar{x}=21 \times$ $7 \mu \mathrm{m}, \mathrm{n}=20$ ), biseriate, partially overlapping, dark brown, $\mathrm{K}+$ turning black, often paler brown in the spore tips, narrowly ellipsoid, 3-septate, often slightly curved, sometimes slightly curved toward the ends, constricted at the septa, smooth, without a gelatinous sheath. Asexual morph: undetermined.

Material examined - REPUBLIC OF MADAGASCAR, Province. Diego Suarez, Antsiranana, W of Sambava, Marojejy National Park, along the trail from Camp Simpona to summit, $1853 \mathrm{~m}, 14^{\circ} 26^{\prime} 41^{\prime \prime} \mathrm{S}, 4^{\circ} 44^{\prime} 13^{\prime \prime} \mathrm{E}$, rather dense humid montane forest grading into dense sclerophyllous upper montane forests, on twig of shrub, on Parmeliaceae, 20 October 2014, Ertz 20089 (BR).

Notes - Pyrenidium aggregatum was described from USA by Knudsen \& Kocourkova (2010). Our specimen fits well $P$. aggregatum which is characterized by distinct convex galls, with completely immersed perithecia, 8-spored and rather small ascospores. The holotype of $P$. aggregatum was reported from Phaeophyscia rubropulchra (Physciaceae), while our collection is reported from Parmeliaceae. Thus, we prefer to use "aff." for our specimen because of the different lichen family of the host and the distant geographic locality (Madagascar).

Pyrenidium borbonicum Huanraluek, Ertz \& K.D. Hyde, sp. nov

Figs 5, 6

Index Fungorum number: IF556643; Facesoffungi number: FoF06297

Etymology - named after Bourbon Island, the old name for Reunion Island.

Holotype - Reunion Island; Cilaos, trail to the Col du Taibit, Plateau de la Fraise, ca 1,700 m, 2106'45”S, 55²6’35”'E, mossy rocky slope, on Sticta, 12 December 2012, D. Ertz 18066 (BR).

Ascomata in groups immersed in the host-thallus, only the upper, blackish part of the ascomata visible, $94-221 \times 77-166 \mu \mathrm{m}(\bar{x}=172 \times 129 \mu \mathrm{m}, \mathrm{n}=10)($ Ertz 18031), 125-165 $\times 117-$ $184 \mu \mathrm{m}(\bar{x}=151 \times 145 \mu \mathrm{m}, \mathrm{n}=4)($ Ertz 18066), subglobose to broadly ovoid in longitudinal section, with hyaline periphyses in ostiolar channel. Peridium 18-29 $\mu \mathrm{m}$ wide (Ertz 18031) 12-15 $\mu \mathrm{m}$ wide (Ertz 18066), composed of 3-7 layers (Ertz 18031), 4-6 layers (Ertz 18066) of textura prismatica, with isodiametric to elongated cells, brown to dark brown. Hymenium not inspersed. Hamathecial filaments numerous, composed of pseudoparaphyses 2-3 $\mu \mathrm{m}$ diam, richly branched and anastomosing, present between the asci, and periphyses 18-20 $\times 2-4 \mu \mathrm{m}$ (Ertz 18031), 11-24 $\times$ 1-2 $\mu \mathrm{m}$ (Ertz 18066) in ostiole region, apical cell not enlarged. Asci 47-96 $\times 10-16 \mu \mathrm{m}(\bar{x}=71 \times$ $13 \mu \mathrm{m}, \mathrm{n}=20)($ Ertz 18031), 64-98 $\times 11-17 \mu \mathrm{m}(\bar{x}=80 \times 15, \mathrm{n}=20)$ (Ertz 18066), 8-spored, narrowly ellipsoid, ocular chamber not distinct. Ascospores 19-23 $\times 5-8 \mu \mathrm{m}(\bar{x}=21 \times 6 \mu \mathrm{m}, \mathrm{n}=$ 20) (Ertz 18031), 22-27 × 4-8 $\mu \mathrm{m}(\bar{x}=25 \times 6 \mu \mathrm{m}, \mathrm{n}=20)$ (Ertz 18066) biseriate, partially overlapping, dark brown, $\mathrm{K}+$ turning black, often pale brown in the spore tips, narrowly ellipsoid, 3 -septate, sometimes slightly curved toward the ends, constricted at the septa, without a gelatinous sheath. Asexual morph: undetermined.

Additional material examined - FRANCE, Reunion Island, Cilaos, forest of Grand Matarum,

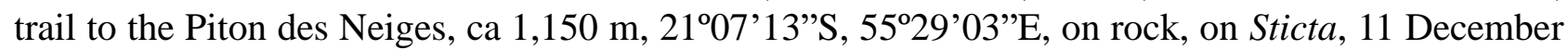
2012, Ertz 18031 (BR). 
Notes - Pyrenidium borbonicum differs from $P$. aggregatum by the absence of strongly convex gall formation (Knudsen $\&$ Kocourkova 2010). It differs from $P$. actinellum by 8-spored asci and narrower ascospores. Phylogenetically, P. borbonicum forms a distinct lineage with high bootstrap supports (MP 100\%/ML 100\%/ BYPP 1.00, Fig. 1).
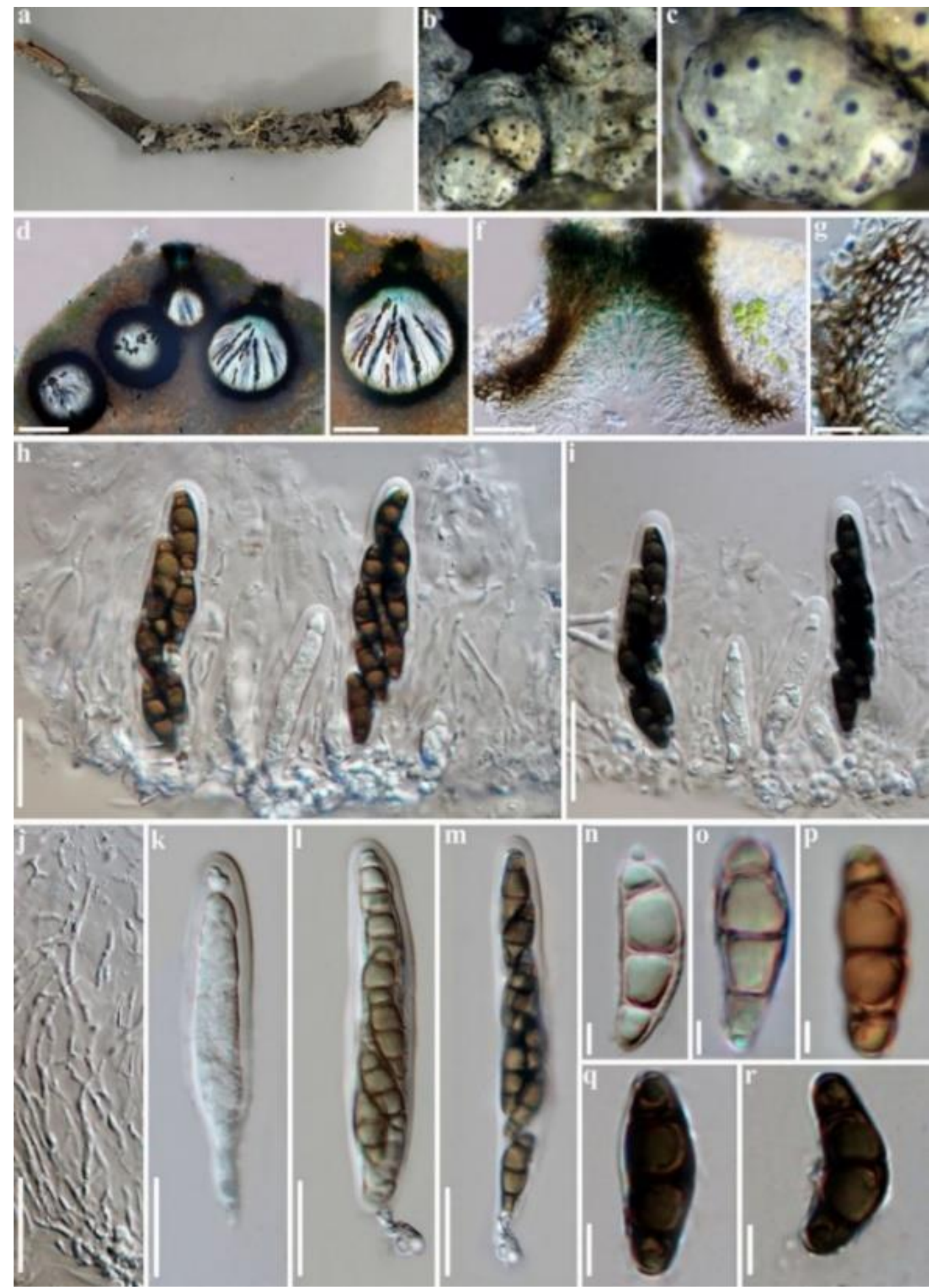

Figure 4 - Pyrenidium aff. aggregatum (Ertz 20089) a-c Appearance of ascomata on host surface. $\mathrm{d}$ Vertical section of a gall with four perithecioid ascomata visible. e Vertical section of one perithecioid ascoma. f Ostiol. g Peridium. h Hymenium with asci in water. i Hymenium in $\mathrm{KOH}$ and brownish ascospores that turned black. $\mathrm{j}$ Pseudoparaphyses, $\mathrm{k}-\mathrm{m}$ Asci. $\mathrm{n}-\mathrm{r}$ Ascospores. Scale bars: $\mathrm{d}-\mathrm{e}=50 \mu \mathrm{m}, \mathrm{f}=20 \mu \mathrm{m}, \mathrm{g}=10 \mu \mathrm{m}, \mathrm{h}=20 \mu \mathrm{m}, \mathrm{i}=20 \mu \mathrm{m}, \mathrm{j}=20 \mu \mathrm{m}, \mathrm{k}-\mathrm{m}=20 \mu \mathrm{m}, \mathrm{n}-\mathrm{r}=5$ $\mu \mathrm{m}$. 

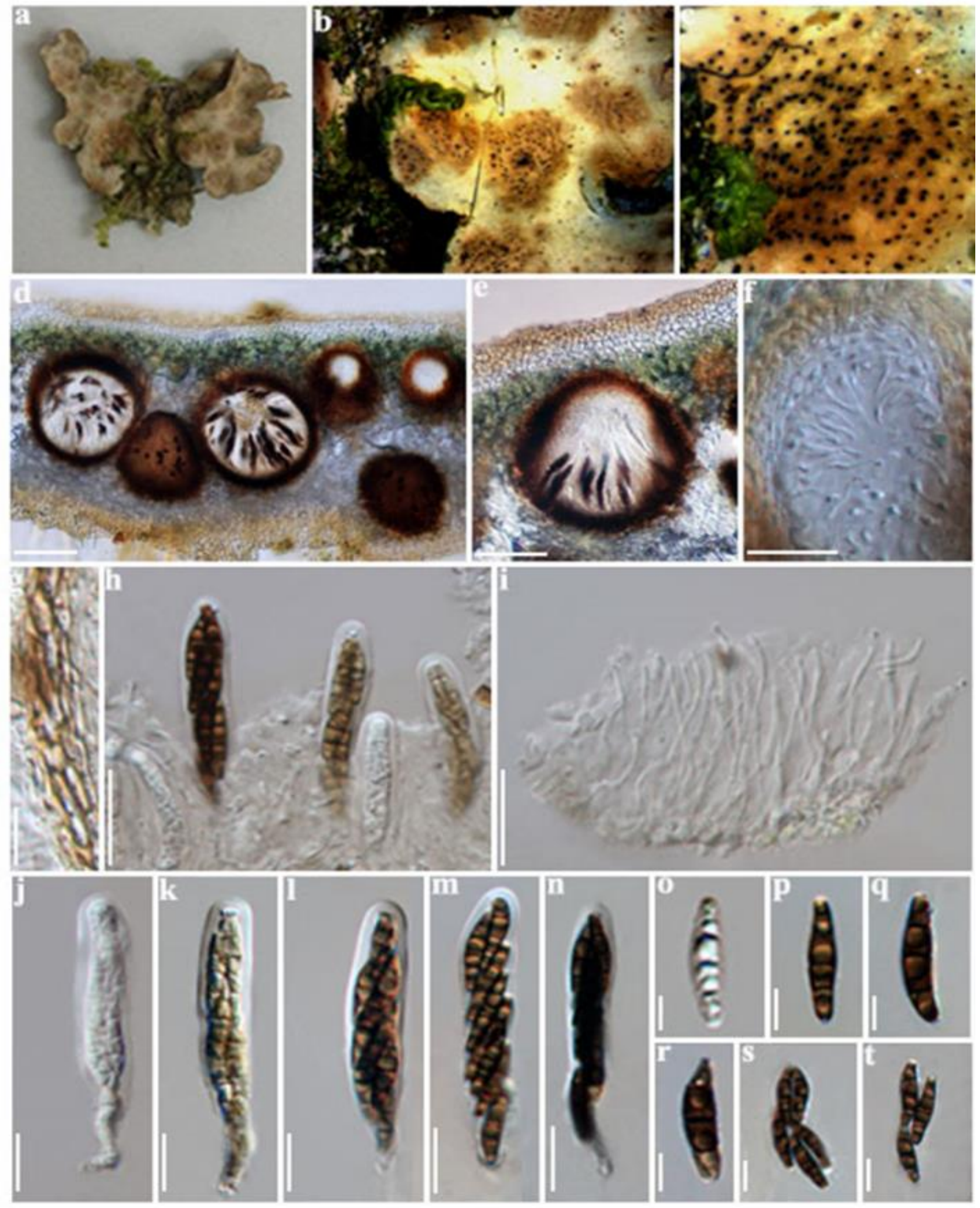

Figure 5 - Pyrenidium borbonicum (Ertz 18066 - holotype) a-c Appearance of ascomata on host surface. d Vertical section of host with perithecioid ascomata visible. e Vertical section of perithecioid ascoma. f Ostiolar channel. g Peridium. h Hymenium with asci. i Pseudoparaphyses, $\mathrm{j}-\mathrm{m}$ Asci in water. $\mathrm{n}$ Asci in $\mathrm{KOH}$ showing the ascospores with the brownish pigment that turned black. o-t Ascospores. Scale bars: $\mathrm{d}-\mathrm{e}=100 \mu \mathrm{m}, \mathrm{f}=50 \mu \mathrm{m}, \mathrm{g}=10 \mu \mathrm{m}, \mathrm{h}=20 \mu \mathrm{m}, \mathrm{i}=20 \mu \mathrm{m}$, $\mathrm{j}-\mathrm{n}=20 \mu \mathrm{m}, \mathrm{o}-\mathrm{t}=10 \mu \mathrm{m}$. 

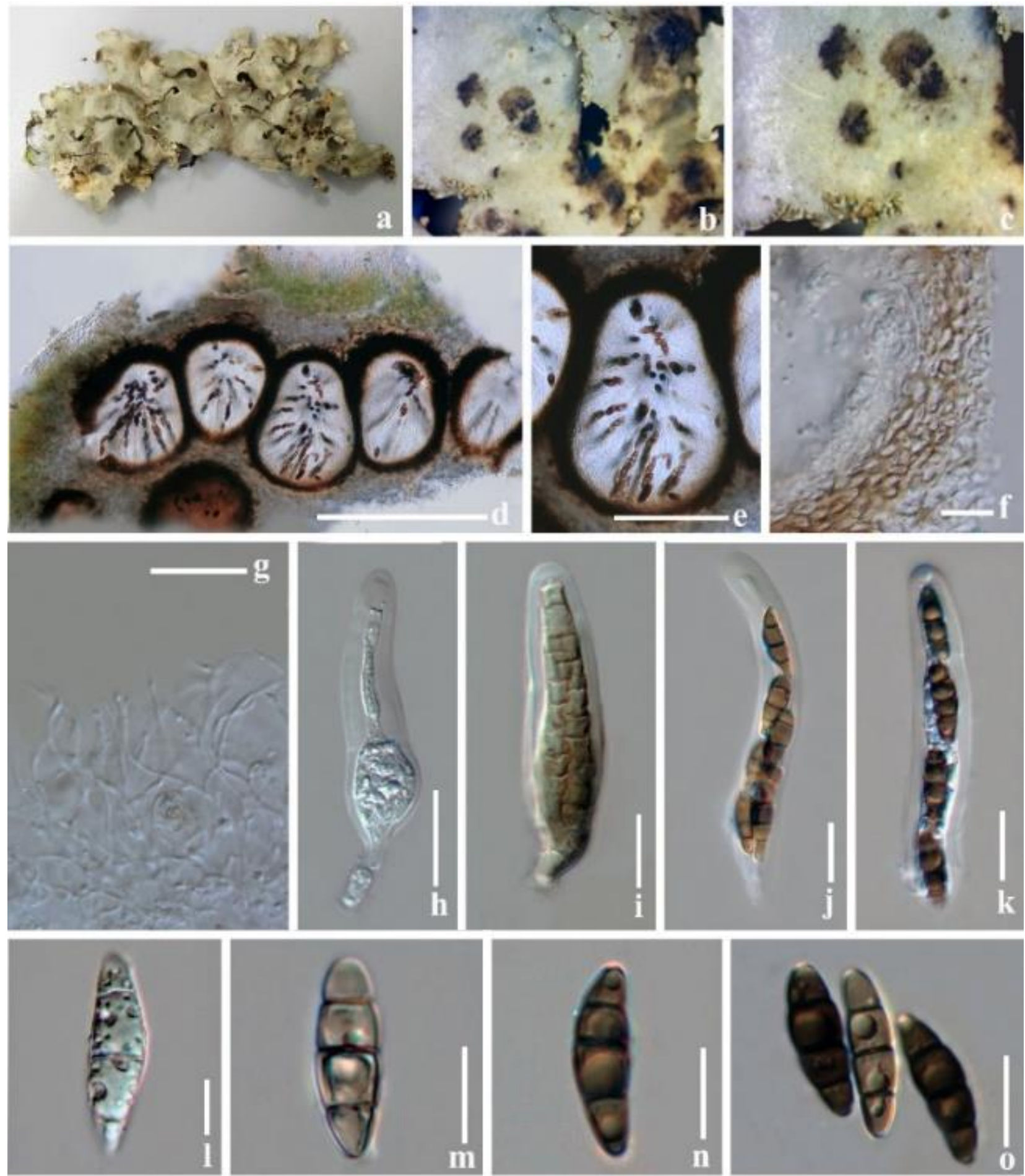

Figure 6 - Pyrenidium borbonicum (Ertz 18031) a-c Appearance of ascomata on host surface. $\mathrm{d}$, e Vertical section of perithecioid ascomata. f Peridium. g Pseudoparaphyses. h-k Asci in water. l-o Ascospores. Scale bars: $\mathrm{d}, \mathrm{e}=50 \mu \mathrm{m}, \mathrm{f}=20 \mu \mathrm{m}, \mathrm{g}-\mathrm{k}=20 \mu \mathrm{m}, 1-\mathrm{o}=10 \mu \mathrm{m}$.

\section{Discussion}

The family Dacampiaceae was shown to be polyphyletic by Ertz et al. (2015), with several genera (viz. Clypeococcum, Munkovalsaria and Polycoccum) transferred to other families and orders. Dacampiaceae was placed in the Pleosporales based on DNA sequence data of its type genus (Dacampia). Since then, the monophyly of Dacampiaceae as currently accepted has never been tested, and there is a lack of molecular data for its six other currently accepted genera. Our phylogenetic analyses using new nuLSU and nuSSU sequence data indicate that Pyrenidium does 
not belong to the Dacampiaceae (Fig. 1). Despite these phylogenetic analyses, Dacampiaceae still appears to be a heterogeneous assemblage of genera (e.g. unbranched vs. branched pseudoparaphyses, slit-like vs. punctiform ostiole). Therefore, it is likely that molecular studies of the other genera currently included in Dacampiaceae can lead to further dismantling of the family.

Pyrenidium has affinities with genera of Dacampiaceae by having a lichenicolous habit, perithecioid ascomata, a similar ascus type, and brown ascospores, but differs notably by different type of ascospores (Table 3). The closest relatives of Pyrenidium are Natipusillaceae (Natipusillales), Microthyriaceae (Microthyriales) and Zeloasperisporiaceae (Zeloasperisporiales) but these are not well supported (Fig. 1). A more robust phylogeny is needed to confirm this relationship using markers that are more informative than the nuLSU and nuSSU loci.

The family Natipusillaceae was described for saprobic fungi living on submerged wood in fresh water habitats of the neo-tropical environment (Raja et al. 2012, Hyde et al. 2013). Species of Natipusilla differs from Pyrenidium notably by hyaline to light brown ascomata, globose, subglobose or obclavate asci, fusiform to cylindrical, hyaline (but becoming brown with age) ascospores sometimes having gelatinous appendages and a very different life habit being saprobic on submerged wood (Ferrer et al. 2011, Raja et al. 2012, Hyde et al. 2013). Microthyriaceae are reported as epiphytes on dried leaves of plants. In addition to the substrate, species of Microthyriaceae differ from Pyrenidium by thyriothecioid ascomata with hyaline, rarely brown, usually 1-septate ascospores (Müller \& von Arx 1962, Ellis 1976, Ramaley 1999, von Arx \& Müller 1975, Barr 1987, Hawksworth et al. 1995, Lumbsch \& Huhndorf 2010, Wu et al. 2010, 2011, b, Hyde et al. 2013). Zeloasperisporiaceae are reported as saprobes on dead and living leaves (Wu et al. 2011, Hongsanan et al. 2015). This family can be distinguished from Pyrenidium by thyriothecioid, superficial ascomata, globose to ovoid or clavate, apedicellate asci and 1-septate, hyaline, asymmetric ascospores (Jayasiri et al. 2018). Based on our molecular results and the morphology, the family Pyrenidiaceae is resurrected from its synonymy with Dacampiaceae.

Pyrenidium actinellum has been recorded from a wide range of lichen host genera (e.g. Hawksworth 1983) but the species is considered to be heterogeneous. In our phylogenetic analyses, specimen '16557' from Belgium grows on the same lichen host genus as the type, i.e. Scytinium plicatile. It also shares morphological characters with the lectotype of $P$. actinellum, such as the 4spored asci (Table 2). Therefore, we consider specimen 16557 to represent P. actinellum sensu stricto.

Most of the 2000 obligately lichenicolous taxa known worldwide are assumed to be restricted to a single host genus (Diederich et al. 2018). In our phylogenetic tree, specimen ' 18063 ' from Reunion groups with $P$. actinellum sensu stricto (strain Ertz 16557). The vouchers also have 4spored asci and probably belong to the same species. Interestingly, specimen ' 18063 ' has a different host genus (=Solorina), suggesting that $P$. actinellum can grow on different host lichen genera (Scytinium and Solorina). However, further studies should test if $P$. actinellum sensu stricto is also able to grow on lichens having green algae as photobiont (cyanobacteria in Scytinium and Solorina). This species is also reported from different lichen genera having trebouxioid photobionts such as Caloplaca, Phaeophyscia, Teloschistes and Trapeliopsis (e.g. Navarro-Rosinés \& Roux 2007). The closest relative of these two specimens of $P$. actinellum is $P$. aff. aggregatum (specimen 20089) from Madagascar. It differs from $P$. actinellum sensu stricto notably by the formation of strongly convex galls, more immersed perithecia, 8-spored asci and a lichen host having trebouxioid photobiont (Table 2). The new species $P$. borbonicum from Reunion is more similar to $P$. aff. aggregatum by its 8 -spored asci and size of ascospores, but it is phylogenetically distinct from $P$. cf. actinellum and $P$. aff aggregatum (Fig. 1). A hidden diversity might be expected in this genus as revealed by the discovery of the new species that is genetically clearly deviant from $P$. actinellum, a name that perhaps has been misused for the identification of Pyrenidium specimens from various host genera. 
Table 2 Comparison of Pyrenidium species. Species in this study are in bold. Pyrenidium ucrainicum is probably a synonym of Didymocyrtis ramalinae according to Ertz et al. (2015).

\begin{tabular}{|c|c|c|c|c|c|c|}
\hline Pyrenidium species & $\begin{array}{l}\text { Perithecioid ascomata } \\
\text { size }(\mu \mathrm{m})\end{array}$ & $\begin{array}{c}A s c i \\
\text { size }(\mu \mathrm{m})\end{array}$ & $\begin{array}{l}\text { Ascospores } \\
\text { size }(\mu \mathrm{m})\end{array}$ & $\begin{array}{c}\text { Number of } \\
\text { ascospores per } \\
\text { asci } \\
\end{array}$ & Host Lichen & References \\
\hline $\begin{array}{l}\text { Pyrenidium actinellum } \\
\text { (holotype, } \mathrm{BM} \text { ) }\end{array}$ & $130-188 \times 150-190$ & $40-88 \times 11-18$ & $\begin{array}{l}\text { 19-27 × 7-9, } \\
\text { 3-septate }\end{array}$ & 4-spored & Scytinium teretiusculum & Doilom et al. (2018) \\
\hline $\begin{array}{l}\text { Pyrenidium aff. aggregatum } \\
\text { (Ertz 20089) }\end{array}$ & $45-106 \times 33-79$ & $48-87 \times 11-18$ & $\begin{array}{l}\text { 19-22 × 7-9, } \\
\text { 3-septare }\end{array}$ & 8-spored & Parmeliaceae & This study \\
\hline $\begin{array}{l}\text { Pyrenidium actinellum Nyl. } \\
\text { sensu stricto. (Ertz 16557) }\end{array}$ & $175-380 \times 162-350$ & $75-80 \times 12-16$ & $\begin{array}{l}\text { 18-26 } \times 8-11 \\
3 \text {-septate }\end{array}$ & 4-spored & Scytinium plicatile & This study \\
\hline Pyrenidium aggregatum & $150-250$ & $85-95 \times 17-20$ & $\begin{array}{l}15-21 \times 6.5-8.5 \\
3 \text {-septate }\end{array}$ & 8-spored & $\begin{array}{l}\text { Phaeophyscia ssp. and } \\
\text { Physcia atrostriata }\end{array}$ & $\begin{array}{l}\text { Knudsen \& Kocourkova } \\
\text { (2010) }\end{array}$ \\
\hline $\begin{array}{l}\text { Pyrenidium borbonicum (Ertz } \\
\text { 18031) }\end{array}$ & $94-221 \times 77-166$ & $47-96 \times 10-16$ & $\begin{array}{l}\text { 19-23 } \times 5-8 \\
\text { 3-septate }\end{array}$ & 8-spored & Sticta & This study \\
\hline $\begin{array}{l}\text { Pyrenidium borbonicum (Ertz } \\
\text { 18066) }\end{array}$ & $125-165$ × 117-184 & $64-98 \times 11-17$ & $\begin{array}{l}\text { 22-27 × 4-8, } \\
\text { 3-septare }\end{array}$ & 8-spored & Sticta & This study \\
\hline $\begin{array}{l}\text { Pyrenidium cf. actinellum } \\
\text { (Ertz 18063) }\end{array}$ & $168-205 \times 117-179$ & $51-115 \times 12-18$ & $\begin{array}{l}20-25 \times 6-11 \\
3 \text {-septate }\end{array}$ & 4-spored & Solorina simensis & This study \\
\hline Pyrenidium coccineum & $200-300$ & - & $\begin{array}{l}17-21 \times 7.5-8.5 \\
3 \text {-septate }\end{array}$ & 8-spored & Siphula decumbens & Aptroot (2014) \\
\hline Pyrenidium cryptotheciae & $100-150 \times 80-150$ & $55-80 \times 10-14$ & $\begin{array}{l}9-13 \times 4-6 \\
\text { 3-septate }\end{array}$ & 8-spored & Cryptothecia candida & Matzer (1996) \\
\hline Pyrenidium hetairizans & $75-150$ & - & $\begin{array}{l}24-26 \times 6-9,3- \\
\text { septate }\end{array}$ & 6-8spored & Verrucaria hydrela & Hawksworth (1986) \\
\hline Pyrenidium hypotrachynae & $63-90 \times 85-110$ & $50-70 \times 8.5-11$ & $\begin{array}{l}22.5-28 \times 5-11 \\
3 \text {-septate }\end{array}$ & 4- spored & Hypotrachyna coorgiana & Joshi et al. (2018) \\
\hline Pyrenidium octosporum & - & $65 \times 28$ & $\begin{array}{l}20-26 \times 7-10 \\
3 \text {-septate }\end{array}$ & 8-spored & an unidentified lichen & Looman (1963) \\
\hline Pyrenidium santessonii & $50-100$ & $50-60 \times 10-13$ & $\begin{array}{l}13-15 \times 4-5 \\
3 \text {-septate }\end{array}$ & 8-spored & $\begin{array}{l}\text { Bacidia psychotriae and } \\
\text { Bapalmuia sp. }\end{array}$ & Lücking (1998) \\
\hline Pyrenidium sporopodiorum & $110-150 \times 100-120$ & $45-65 \times 9-11$ & $\begin{array}{l}12-18 \times 5-6 \\
(2)-3 \text {-septate }\end{array}$ & 4-spored & $\begin{array}{l}\text { Sporopodium cf. leprieurii } \\
\text { var. citrinum }\end{array}$ & Matzer (1996) \\
\hline Pyrenidium ucrainicum & $180-300 \times 150-250$ & $\begin{array}{l}80-85 \times(7.5-) 8- \\
10\end{array}$ & $\begin{array}{l}12-22 \times 4.5-7 \\
3(-4) \text {-septate }\end{array}$ & 8-spored & Ramalina sp. & Kondratyuk et al. (2014) \\
\hline Pyrenidium zamiae & $100-170 \times 100-150$ & $48-70 \times 10-14$ & $\begin{array}{l}15-22 \times 4-6 \\
3 \text {-septate }\end{array}$ & 6-8-spored & Porina epiphylla, $P$. ludica & Matzer (1996) \\
\hline
\end{tabular}


Table 3 Morphological characters of Dacampiaceae and Pyrenidiaceae.

\begin{tabular}{|c|c|c|c|c|c|}
\hline Family & $\begin{array}{c}\text { Fruiting body } \\
\text { Character }\end{array}$ & Peridium & Asci character & Ascospores character & References \\
\hline Dacampiaceae & $\begin{array}{l}\text { Ascomata perithecioid, } \\
\text { blackish with a central } \\
\text { ostiole. } \\
\text { Includes lichenicolous, } \\
\text { lichenized and saprobic } \\
\text { fungi. }\end{array}$ & $\begin{array}{l}\text { Textura angularis with } \\
\text { thick-walled, reddish } \\
\text { to dark brown cells. }\end{array}$ & $\begin{array}{l}\text { Bitunicate, subcylindrical, } \\
\text { apically thickened ocular } \\
\text { chamber, 8-spored. }\end{array}$ & $\begin{array}{l}\text { 1-2-seriate, pale brown to } \\
\text { dark brown, in mature state, } \\
\text { wall not distinctly paler in } \\
\text { the spore tips, muriform, } \\
\text { ellipsoid to fusiform, often } \\
\text { constricted at the septa, } \\
\text { smooth, without visible } \\
\text { gelatinous sheath. }\end{array}$ & $\begin{array}{l}\text { Lutzoni et al. 2004, } \\
\text { Zhang et al. } 2009, \\
\text { Hyde et al. } 2013 \text {, } \\
\text { Ertz et al. } 2015 .\end{array}$ \\
\hline Pyrenidiaceae & $\begin{array}{l}\text { Ascomata perithecioid, } \\
\text { blackish with a central } \\
\text { ostiole. } \\
\text { Some species with light } \\
\text { greenish-blue tint in } \\
\text { ostiole. } \\
\text { Includes lichenicolous. }\end{array}$ & $\begin{array}{l}\text { Textura angularis to } \\
\text { Textura prismatica } \\
\text { with thick-walled, } \\
\text { composed of several } \\
\text { layers of dark brown } \\
\text { to reddish brown. }\end{array}$ & $\begin{array}{l}\text { Bitunicate, narrowly } \\
\text { ellipsoid, shortly } \\
\text { pedicellate, 4-8-spored. }\end{array}$ & $\begin{array}{l}\text { 1-2-seriate, reddish brown } \\
\text { to dark brown in mature } \\
\text { state, paler in , the spore } \\
\text { tips, oblong to ellipsoidal, or } \\
\text { fusiform usually } 3 \text {-septate, } \\
\text { constricted at the septa, } \\
\text { smooth-walled, with the two } \\
\text { inner cells often much larger } \\
\text { than the end cells, without } \\
\text { visible gelatinous sheath. }\end{array}$ & This study \\
\hline
\end{tabular}

\section{Acknowledgements}

Field trip in Réunion were made possible through the courtesy of Benoît Lequette with the help of the Office National des Forêts and the Parc National de La Réunion; while we benefited from the help of the Missouri Botanical Garden offices at Antananarivo, the Parc Botanique et Zoologique de Tzimbazaza at Antananarivo and of the Ministère de l'Environnement, de l'Ecologie et des Forêts in Madagascar. Damien Ertz would like to thank in particular Rogerlala Andriamiandrisoa, Eberhard Fischer, Bernard Goffinet, Tahina Razafindrahaja and Emmanuël Sérusiaux for the field trip in Madagascar. Damien Ertz also acknowledges financial support from the Fonds National de la Recherche Scientifique (FNRS) from Belgium. His expedition to Madagascar in 2014 was financially supported by the Fond Léopold III (LF/JVG/vm/14.75). Authors would like to thank Shaun Pennycook for the checking the species names. Chayanard Phukhamsakda would like to thank the RGJ for a personal grant (The scholarship no. PHD/0020/2557 to study towards a PhD) and Kevin D. Hyde would like to thank the grants entitled: 1 . The future of specialist fungi in a changing climate: baseline data for generalist and specialist fungi associated with ants, Rhododendron species and Dracaena species (Grant number: DBG6080013); 2. Impact of climate change on fungal diversity and biogeography in the Greater Mekong Subregion (Grant number: RDG6130001). 


\section{References}

Aptroot A. 2014 - Two new genera of Arthoniales from New Caledonia and the Solomon Islands, with the description of eight further species. The Bryologist 117 (3), 282-289.

Barr ME. 1987 - Prodomus to class Loculoascomycetes. Publ. by the author, Amherst, Massachusetts.

Crivelli PG. 1983 - Ueber die heterogene Ascomycetengattung Pleospora Rabh. Vorschlag für eine Aufteilung, Zürich. Diss. ETH Nr. 7318. pp 1-215.

Diederich P, Lawrey JD, Ertz D. 2018 - The 2018 classification and checklist of lichenicolous fungi, with 2000 non-lichenized, obligately lichenicolous taxa. The Bryologist 121, 340-425.

Doilom M, Hyde KD, Phookamsak R, Dai DQ et al. 2018 - Mycosphere Notes 225-274: types and other specimens of some genera of Ascomycota, Mycosphere 9, 647-754. Doi10.5943/mycosphere/9/4/3

Ellis JP. 1976 - British Microthyrium species and similar fungi. Transactions of the British Mycological Society. 7(3), 381-194. https://doi.org/10.1016/S0007-1536(76)80162-3

Eriksson OE, Hawksworth DL. 1993 - Outline of the ascomycetes 1993. Syst Ascomycetum 12, 51-257.

Ertz D, Diederich, P, Lawrey JD, Berger F et al. 2015 - Phylogenetic insights resolve Dacampiaceae (Pleosporales) as polyphyletic: Didymocyrtis (Pleosporales, Phaeosphaeriaceae) with Phoma-like anamorphs resurrected and segregated from Polycoccum (Trypetheliales, Polycoccaceae fam. nov.). Fungal Diversity 74 (1), 53-89. http://doi:10.1007/s13225-015-0345-6.

Ferrer A, Miller AN, Shearer CA. 2011 - Minutisphaera and Natipusilla: two new genera of freshwater Dothideomycetes. Mycologia 103, 411-423.

Gargas A, Taylor JW. 1992 - Polymerase chain reaction (PCR) primers for amplifying and sequencing nuclear 18S rDNA from lichenized fungi. Mycologia 84(4), 589-592.

Hawksworth DL. 1977 - Taxonomic and biological observations on the genus Lichenoconium (Sphaeropsidales). Persoonia 9, 159-198.

Hawksworth DL. 1980 - Notes on some fungi occurring on Peltigera, with a key to accepted species. Transactions of the British Mycological Society 74, 363-386.

Hawksworth DL. 1982 - Secondary fungi in lichen symbioses, parasites, saprophytes and parasymbionts. Journal of the Hattori Botanical Laboratory 52, 357-366.

Hawksworth DL. 1983 - The identity of Pyrenidium actinellum Nyl. Transactions of the British Mycological Society 80, 547-549.

Hawksworth DL. 1986 - Notes on British lichenicolous fungi: Version. Notes from the Royal Botanic Garden Edinburgh 43, 497-519.

Hawksworth DL, Kirk PM, Sutton BC, Pegler DN. 1995 - Ainsworth \& Bisby's dictionary of the fungi, 8th edn. CABI, Wallingford.

Hongsanan S, Tian Q, Bahkali AH, Yang JB et al. 2015 - Zeloasperisporiales ord. nov., and two new species of Zeloasperisporium. Cryptogamie, Mycologie 36 (3), 301-317. https://doi.org/10.7872/crym/v36.iss3.2015.301

Hyde KD, Jones EBG, Liu JK, Ariyawansa H et al. 2013 - Families of Dothideomycetes. Fungal Diversity 63, 1-313. http://doi.org/10.1007/s13225-013-0263-4

Jaklitsch W, Baral HO, Lücking R, Lumbsch HT, Frey W. 2016 - Ascomycota. In: Frey W (ed) Syllabus of plant families, Adolf Engler's Syllabus der Pflanzenfamilien 13th edn. Borntraeger Science Publishers, Stuttgart.

Jayasiri SC, Hyde KD, Jones EBG, Jianchu Xu, Karunarathna SC. 2018 - Seed decaying Dothideomycetes in Thailand: Zeloasperisporium pterocarpi sp. nov., (Zeloasperisporiaceae, Zeloasperisporiales) on carpel of Pterocarpus sp. (Fabaceae) seed pod. Asian Journal of Mycology 1(1), 106-113.

Joshi Y, Tripathi M, Bisht K, Upadhyay S et al. 2018 - Further contributions to the documentation of lichenicolous fungi from India. Kavaka 50, 26-33. 
Katoh K, Standley DM. 2016 - MAFFT multiple sequence alignment software version 7: improvements in performance and usability. Molecular biology and Evolution 30, 772-780. http://dx.doi.org/10.1093/molbev/mst010.

Kauff F, Lutzoni F. 2002 - Phylogeny of the Gyalectales and Ostropales (Ascomycota, Fungi): among and within order relationships based on nuclear ribosomal RNA small and large subunits. Molecular Phylogenetics and Evolution 25, 138-156.

Knudsen K, Kocourková J. 2010 - Pyrenidium aggregatum, a new species from North America. Opuscula Philolichenum 8, 71-74.

Kondratyuk SY, Lökös L, Hur JS. 2014 - New lichen-forming and lichenicolous fungi from Ukraine. Acta Botanica Hungarica 56, 3-4.

Körber GW. 1855 - Systema lichenum Germaniae 322.

Lendemer JC. 2017 - Recent literature on lichens-245. The Bryologist 120 (2), 236-256. https://doi.org/10.1639/0007-2745-120.2.236

Lumbsch HT, Huhndorf SM. 2010 - Myconet Volume 14. Part one. Outline of Ascomycota 2009. Part Two. Notes on Ascomycete Systematics. Nos. 4751-5113. Fieldiana Life Earth Science $1,1-64$.

Lutzoni F, Kauff F, Cox CJ, McLaughlin D et al. 2004 - Assembling the fungal tree of life: progress, classification, and evolution of subcellular traits. American Journal of Botany 91, 1446-1480. https://doi.org/10.3732/ajb.91.10.1446

Matzer M. 1996 - Lichenicolous ascomycetes with fissitunicate asci on foliicolous lichens, Mycological paper 171, 1-202.

Miadlikowska J, McCune B, Lutzoni F. 2002 - Pseudocyphellaria perpetua, a new lichen from Western North America. The Bryologist 105, 1-10.

Miller MA, Pfeiffer W, Schwartz T. 2011 - Creating the CIPRES Science Gateway for inference of large phylogenetic trees. In: Proceedings of the Gateway Computing Environments Workshop (GCE). New Orleans, LA. CA, San Diego Supercomput. Center, pp. 1-8. http://www.phylo.org/index.php/portal/about/

Muscavitch ZM, Lendemer JC, Harris RC. 2017 - A synopsis of the lichenicolous fungi occurring on Phlyctis including description of a new Monodictys widespread on P. speirea. The Bryologist 120 (4), 418-426. https://doi.org/10.1639/0007-2745-120.4.418

Müller E, von Arx JA. 1962 - Die Gattungen der didymosporen Pyrenomyceten. Beiträge zur Kryptogamenflora der Schweiz 11(2), 1-922.

Navarro-Rosinés P, Roux Cl. 2007 - Pyrenidium Nyl. 1865 - In: Lichen Flora of the Greater Sonoran Desert Region. Vol. 2. (eds TH Nash III, BD Ryan, P Diederich, C Gried, F Bungartz). Lichens Unlimited, Arizona State University, Tempe, Arizona 404-405.

Nylander JAA. 2004 - MrModeltest Version 2. Program distributed by the author. Evolutionary Biology Center, Uppsala University.

Nylander W. 1865 - Novitiae quaedam Lichenum Europaeorum variarum tribuum. Flora (Regensburg), Flora 48: 209-213.

Pirogov M. 2014 - Ascomata micromorphology of Pyrenidium actinellum s.l. (Dacampiaceae, Ascomycota). Modern Phytomorphology 5, 275-27. https://doi.org/10.5281/zenodo.161038

Raja HA, Miller AN, Shearer CA. 2012 - Freshwater ascomycetes: Natipusillaceae, a new family of tropical fungi, including Natipusilla bellaspora sp. nov. from the Peruvian Amazon. Mycologia 104, 569-573.

Ramaley AW. 1999 - Three species of Microthyrium from Nolina. Mycotaxon 70, 7-16.

Rambaut A. 2012 - FigTree Tree Version 1.4.0. Figure Drawing Tool 2006-2012.

Rannala B, Yang Z. 1996 - Probability distribution of molecular evolutionary trees: a new method of phylogenetic inference. Journal of Molecular Evolution 43, 304-311.

https://doi.org/10.1007/BF02338839

Ronquist F, Huelsenbeck J, Teslenko M. 2011 - Draft MrBayes version 3.2. Manual: tutorials and model summaries. Bioinformatics 85-131.

Swofford DL. 2002 - PAUP: phylogenetic analysis using parsimony, version 4.0 b10. Sinauer 
Associates, Sunderland.

Tamura K, Stecher G, Peterson D, Peterson D et al. 2013 - MEGA6: molecular evolutionary genetics analysis version 6.0. Molecular Biology and Evolution mst197. http://dx.doi.org/10.1093/molbev/mst197.

Thambugala KM, Hyde KD, Tanaka K, Tian Q et al. 2015 - Towards a natural classification and backbone tree for Lophiostomataceae, Floricolaceae, and Amorosiaceae fam. nov. Fungal Diversity 74: 199-266. http://doi.org/10.1007/s13225-015-0348-3

Vilgalys R, Hester M. 1990 - Rapid genetic identification and mapping of enzymati-cally amplified ribosomalDNAfromseveral Cryptococcus species. Journal of Bacteriology 172, 4238-4246.

von Arx JA, Müller E. 1975 - A re-evaluation of the bitunicate ascomycetes with key to families and genera. Studies in Mycology 9, 1-159.

Wijayawardene NN, Crous PW, Kirk PM, Hawksworth DL et al. 2014 - Naming and outline of Dothideomycetes - 2014 including proposals for the protection or suppression of generic names. Fungal Diversity 69: 1-55.

Wijayawardene NN, Hyde KD, Lumbsch HT, Liu JK et al. 2018 - Outline of Ascomycota: 2017. Fungal Diversity 88 (1), 167-263. https://doi.org/10.1007/s13225-018-0394-8

Wu HX, Li YM, Chen H, Hyde KD. 2010 - Studies on Microthyriaceae: some excluded genera. Mycotaxon 113, 147-156. https://doi.org/10.5248/113.147

Wu HX, Hyde KD, Chen H. 2011a - Studies on Microthyriaceae: placement of Actinomyxa, Asteritea, Cirsosina, Polystomellina and Stegothyrium. Cryptogamie Mycologie 32, 3-12. https://doi.org/10.7872/crym.v32.iss1.2012.003

Zhang Y, Schoch CL, Fournier J, Crous PW et al. 2009 - Multi-locus phylogeny of the Pleosporales: a taxonomic, ecological and evolutionary reevaluation. Studies in Mycology 64, 85-102. https://doi.org/10.3114/sim.2009.64.04

Zhaxybayeva O, Gogarten JP. 2002 - Bootstrap, Bayesian probability and maximum likelihood mapping: exploring new tools for comparative genome analyses. BMC Genomics 3: 4. https://doi.org/10.1186/1471-2164-3-4 